\title{
Emphysematous Pyelonephritis in a Renal Transplant Patient
}

\author{
Kashif J. Piracha1, Frank Darras², Edward P. Nord', Nand K. Wadhwa1 \\ ${ }^{1}$ Division of Nephrology, Department of Medicine, Stony Brook Medicine, Stony Brook, USA \\ ${ }^{2}$ Transplantation Services, Stony Brook Medicine, Stony Brook, USA \\ Email: nand.wadhwa@stonybrookmedicine.edu
}

Received 24 April 2014; revised 23 May 2014; accepted 8 June 2014

Copyright (C) 2014 by authors and Scientific Research Publishing Inc.

This work is licensed under the Creative Commons Attribution International License (CC BY). http://creativecommons.org/licenses/by/4.0/

(c) (i) Open Access

\begin{abstract}
Emphysematous pyelonephritis (EPN) is a necrotizing bacterial infection of the kidney that is caused by gas-forming organisms. We report a case of a 58-year-old man with a renal transplant who presented to the emergency room with nausea, vomiting and right lower quadrant abdominal pain. At the time of presentation, he was hemodynamically stable, and the abdominal examination was significant for tenderness over the allograft. Urinalysis was positive for large amounts of leukocyte esterase and white blood cells. He received empiric antibiotic coverage with piperacillin/tazobactam. Over the following 24 hours, the patient developed septic shock manifested by hemodynamic instability. A non-contrast CT scan of the abdomen and pelvis elucidated a heterogeneous gas containing collection in the allograft. Emergent transplant nephrectomy was performed. Postoperatively, the patient rapidly recovered and was subsequently discharged home to commence outpatient hemodialysis. A review of the literature suggests that early recognition of the severity of EPN as manifested by hemodynamic instability dictates emergent transplant nephrectomy as the treatment of choice.
\end{abstract}

\section{Keywords}

Emphysematous Pyelonephritis, Kidney Allograft, Transplant

\section{Introduction}

Emphysematous pyelonephritis (EPN) in the transplanted kidney is a rare, severe, often life-threatening condition that is characterized by acute necrotizing infection involving the renal parenchyma and surrounding tissues, caused by gas-forming organisms [1]. Risk factors include diabetes mellitus and urinary tract obstruction caused by calculi, tumors, and strictures [2]. Early recognition and prompt management is needed to obviate the high 
mortality associated with this diagnosis. We report a case of EPN in a renal transplant patient that was successfully treated with emergent nephrectomy. The indications for percutaneous drainage vs transplant nephrectomy are discussed.

\section{Case Report}

A 58-year-old man presented to the emergency room with a one week history of nausea, vomiting, decreased appetite, right lower quadrant abdominal pain and decreased urinary output. His past medical history was significant for end stage renal disease (ESRD) secondary to diabetic nephrosclerosis, and he was the recipient of a deceased donor renal allograft in July 2007. His serum creatinine had stabilized between 1.2 to $1.7 \mathrm{mg} / \mathrm{dl}$ (106.08 to $150.28 \mu \mathrm{mol} / \mathrm{l})$. Immunosuppressive regimen comprised of tacrolimus $4 \mathrm{mg}$ twice daily and mycophenolatemofetil (MMF) 500 mg twice daily. In April 2010 serum creatinine increased to $2.7 \mathrm{mg} / \mathrm{dl}$ (238.68 $\mu \mathrm{mol} / \mathrm{l})$. Transplant kidney biopsy revealed acute $\mathrm{T}$ cell mediated rejection, acute tubular injury and transplant glomerulitis, and he received three doses of intravenous solumedrol. Serum creatinine remained stable at $2.6 \mathrm{mg} / \mathrm{dl}$ (229.84 $\mu \mathrm{mol} / \mathrm{l})$. However, in September 2010 serum creatinine increased to $3.16 \mathrm{mg} / \mathrm{dl}(279.34 \mu \mathrm{mol} / \mathrm{l})$ and a second kidney biopsy was performed. On this occasion, histopathology showed interstitial fibrosis with no evidence of acute rejection. By December 2010, serum creatinine had risen to $5.6 \mathrm{mg} / \mathrm{dl}$ (495.04 $\mu \mathrm{mol} / \mathrm{l})$, and a third kidney biopsy was performed which revealed chronic allograft nephropathy. Following this biopsy, mycophenolic acid level was found to be $<0.5 \mathrm{ug} / \mathrm{ml}$ so the dose of MMF was increased to $1000 \mathrm{mg}$ twice daily. Tacrolimus dose had been maintained at $4 \mathrm{mg}$ twice daily. The serum creatinine improved to $2.97 \mathrm{mg} / \mathrm{dl}$ (262.54 $\mu \mathrm{mol} / \mathrm{l}$ ) over a period of the next four months.

At the time of his current presentation, physical examination revealed a blood pressure of 139/69 mmHg, heart rate of 121 beats/min, temperature of $37.2^{\circ} \mathrm{C}$, and oxygen saturation of $100 \%$ on room air. Abdominal examination revealed right lower quadrant tenderness over the renal allograft. The respiratory, cardiovascular and neurologic examinations were all unremarkable.

Laboratory data showed a white blood cell count of $7.5 \times 10^{3}$ cells $/ \mathrm{mm}^{3}$, hemoglobin $8.4 \mathrm{~g} / \mathrm{dl}$ and platelet count of $49 \times 10^{3}$ cells $/ \mathrm{mm}^{3}$. The serum sodium was $126 \mathrm{mEq} / \mathrm{l}(126 \mathrm{mmol} / \mathrm{l})$, potassium $5.4 \mathrm{mEq} / \mathrm{l}(5.4 \mathrm{mmol} / \mathrm{l})$, chloride $102 \mathrm{mEq} / \mathrm{l}$ (102 mmol/l), and bicarbonate $13 \mathrm{mEq} / \mathrm{l}$ (13 mmol/l). Blood urea nitrogen was $121 \mathrm{mg} / \mathrm{dl}$ (43.19 mmol/l), serum creatinine was $7.8 \mathrm{mg} / \mathrm{dl}$ (689.52 $\mu \mathrm{mol} / \mathrm{l})$, and glucose $377 \mathrm{mg} / \mathrm{dl}$ (20.73 mmol/l). Urinalysis was positive for nitrite, large amounts of leukocyte esterase and $>182 \mathrm{WBC} / \mathrm{hpf}$. An ultrasound of the kidney allograft showed no evidence of hydronephrosis or perinephric fluid collection. The patient was started empirically on piperacillin/tazobactam 2.25 g intravenously every 6 hours for suspected acute pyelonephritis. He also received intravenous fluids with $0.45 \% \mathrm{NaCl}$ with $75 \mathrm{meq} / \mathrm{l}(\mathrm{mmol} / \mathrm{l})$ of sodium bicarbonate at $125 \mathrm{ml} / \mathrm{hr}$.

Over the next 24 hours, he became febrile to $38.4^{\circ} \mathrm{C}$, hypotensive with a blood pressure of $79 / 47 \mathrm{mmHg}$ associated with acute respiratory distress. He was intubated and started on a norepinephrine drip. Physical examination was significant for marked tenderness over the transplanted kidney. Bowel sounds were intact. Repeat laboratory data revealed a white blood cell count of $13 \times 10^{3}$ cells/ $/ \mathrm{mm}^{3}$, hemoglobin $7.6 \mathrm{~g} / \mathrm{dl}$ and platelet count dropped to $14 \times 10^{3}$ cells $/ \mathrm{mm}^{3}$. The serum sodium was $128 \mathrm{mEq} / \mathrm{l}(128 \mathrm{mmol} / \mathrm{l})$, potassium $3.5 \mathrm{mEq} / \mathrm{l}$ (3.5 mmol/l), chloride $90 \mathrm{mEq} / \mathrm{l}(90 \mathrm{mmol} / \mathrm{l})$ and bicarbonate $24 \mathrm{mEq} / \mathrm{l}(24 \mathrm{mmol} / \mathrm{l})$. Blood urea nitrogen was $103 \mathrm{mg} / \mathrm{dl}$ (36.77 mmol/l), serum creatinine was $5.5 \mathrm{mg} / \mathrm{dl}$ (486.2 $\mu \mathrm{mol} / \mathrm{l})$, and glucose $254 \mathrm{mg} / \mathrm{dl}$ (13.97 mmol/l). Both urine and blood cultures grew Klebsiella pneumoniae. A noncontrast CT scan of the abdomen and pelvis revealed a heterogeneous gas containing collection in the surgical bed of the transplanted kidney, consistent with emphysematous pyelonephritis (Figure 1(a) and Figure 1(b)).

In the setting of persistent hypotension, emergent transplant nephrectomy was performed. Immunosuppression was discontinued. Postoperatively, blood pressure rapidly improved to 138/63 mm Hg and he was extubated. A tunneled subclavian catheter was placed and hemodialysis was initiated.

The gross pathological specimen revealed a friable, necrotic, gas filled kidney. The surface showed extensive hemorrhage with areas of yellow exudates (Figure 2(a)). Microscopic examination revealed acute severe pyelonephritis (Figure 2(b)). A two week course of antibiotics with piperacillin/tazobactam was completed. He was subsequently discharged home in stable condition and continued on outpatient maintenance hemodialysis.

\section{Discussion}

We report a case of emphysematous pyelonephritis (EPN) presenting with rapidly progressive multi-organ 


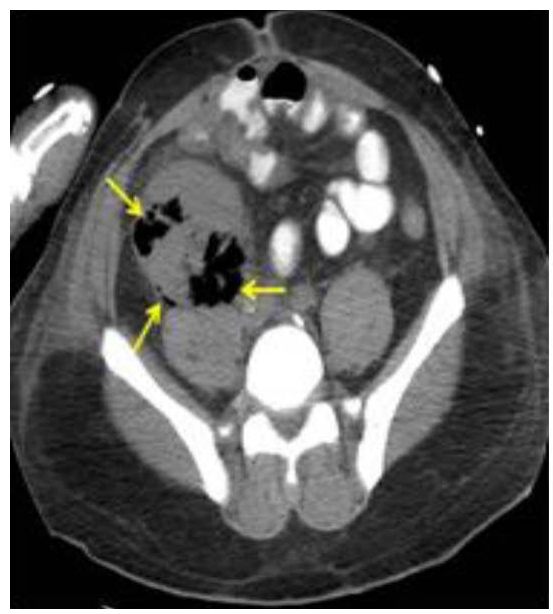

(a)

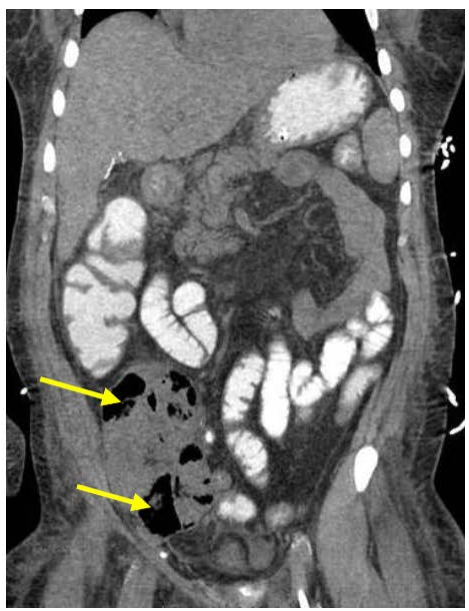

(b)

Figure 1. Axial (a), and sagittal (b) images of the abdomen and pelvis demonstrating an enlarged pelvic kidney with multiple bubbly and linear collections of gas within the renal parenchyma.

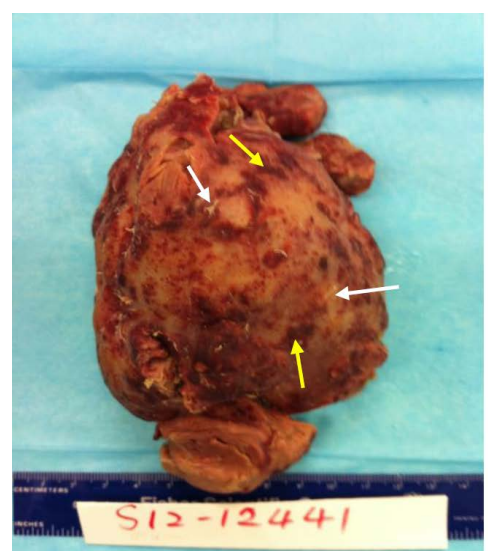

(a)

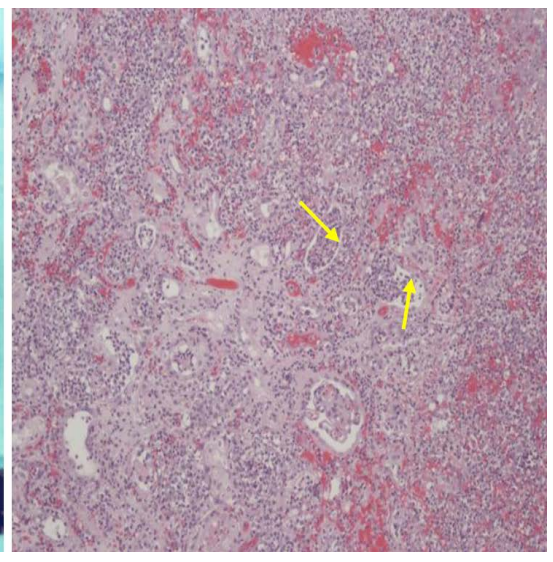

(b)

Figure 2. (a) Surface of the kidney shows areas of hemorrhage (yellow arrows) and exudates (white arrows); (b) Microscopy shows neutrophils within the tubular lumen which is an indication of acute pyelonephritis.

dysfunction and septic shock. The diagnosis of EPN was based primarily on the non-contrast CT scan of the abdomen (Figure 1(a) and Figure 1(b)) that showed a heterogeneous gas collection within the renal allograft. Emergent transplant nephrectomy was performed as a life-saving intervention. Post-operatively, the patient rapidly recovered and was subsequently discharged home on chronic maintenance hemodialysis.

Emphysematous pyelonephritis (EPN) is an acute necrotizing bacterial or fungal infection of the kidney associated with the presence of gas within the renal parenchyma, collecting system or perinephric tissue [1]. While EPN is well described in the native kidney, to the best of our knowledge, only 20 cases have been reported in the transplanted kidney. These data are summarized in Table 1 and include our patient, making the total 21. In this population, mean age of presentation was $47 \pm 15$ years (range 12 - 76 years), and 14/21 patients (67\%) were male. Of note, 19/21 patients (90\%) were diabetic; of these 12/19 patients (63\%) had diabetes mellitus prior to transplantation whereas 7/19 patients (37\%) developed diabetes mellitus post transplantation. EPN developed as early as 4 days, and as late as 15 years after transplantation; in 6/21 patients (29\%) EPN occurred in the first 3 months post transplantation. Deceased donor kidneys accounted for 13/21 (62\%) of occurrences, while 5/21 (24\%) occurred in living donor kidneys. The type of transplant was not stated in 3/21 patients (14\%). The immunosuppressive regimen included prednisone 15/21 (71\%), cyclosporine 10/21 (48\%), azathioprine 6/21 (29\%), 
Table 1. Characteristics of renall allograft recipients with emphysematous pyelonephritis.

\begin{tabular}{|c|c|c|c|c|c|c|c|c|c|c|}
\hline $\begin{array}{c}\text { Case Reports, } \\
\text { Year }\end{array}$ & Age & Gender & $\begin{array}{l}\text { Septic } \\
\text { Shock }\end{array}$ & $\begin{array}{l}\text { Time after } \\
\text { Transplant }\end{array}$ & Diabetes & Organisms & Treatment & $\begin{array}{l}\text { Patient } \\
\text { Outcome }\end{array}$ & $\begin{array}{l}\text { Type of } \\
\text { Transplant }\end{array}$ & Immunosuppression \\
\hline $\begin{array}{l}\text { Parameswaran } \\
\text { et al. [9] } 1977\end{array}$ & 53 & $\mathrm{~F}$ & Y & 7 weeks & $\mathrm{Y}$ (post) & E. coli & Abx, TN & On HD & Deceased & Pred, Aza \\
\hline $\begin{array}{l}\text { Brenbridge et al. } \\
\text { [10] } 1979\end{array}$ & 33 & M & $\mathrm{N}$ & 2 weeks & $\mathrm{Y}$ (post) & E. coli & Abx, TN & On HD & Deceased & Pred, Aza \\
\hline $\begin{array}{c}\text { Balsara et al. [11] } \\
1985\end{array}$ & 32 & M & $\mathrm{N}$ & 1.5 months & $\mathrm{Y}$ (post) & E. coli & Abx, PCD & Recovered & Deceased & Pred, Cyclo \\
\hline $\begin{array}{l}\text { Potter et al. [12] } \\
1985\end{array}$ & 31 & $\mathrm{~F}$ & $\mathrm{~N}$ & 20 months & Y (pre) & E. coli & Abx, TN & On HD & Deceased & Did not mention \\
\hline $\begin{array}{c}\text { Potter et al. [12] } \\
1985\end{array}$ & 39 & M & Y & 3 months & Y (pre) & E. coli & Abx, TN & Died & Deceased & Did not mention \\
\hline $\begin{array}{l}\text { O’Donnell et al. } \\
\text { [13] } 1986\end{array}$ & 27 & M & $\mathrm{N}$ & 5 years & Y (pre) & Enterobacter & Abx & Recovered & Living & Aza, Pred \\
\hline Glen et al. [14] & 66 & $\mathrm{~F}$ & $\mathrm{~N}$ & not given & Y (pre) & E. coli & Abx, PCD & Recovered & Not given & Did not mention \\
\hline $\begin{array}{c}\text { Kalra et al. [15] } \\
1993\end{array}$ & 35 & M & Y & 3 months & $\mathrm{N}$ & Klebsiella & Abx, TN & Died & Living & Cyclo, Pred \\
\hline $\begin{array}{c}\text { Akalin et al. [16] } \\
1996\end{array}$ & 62 & M & $\mathrm{N}$ & 5 years & Y (pre) & Klebsiella & Abx & Recovered & Deceased & Pred, Aza, Cyclo \\
\hline $\begin{array}{l}\text { Cheng et al. [17] } \\
2001\end{array}$ & 55 & M & $\mathrm{N}$ & 7 years & $\mathrm{Y}$ (post) & E. coli & Abx, PCD & Recovered & Deceased & Cyclo, Pred \\
\hline $\begin{array}{l}\text { Iqubal et al. } \\
\text { [18] } 2004\end{array}$ & 39 & $\mathrm{~F}$ & Y & 2 years & $\mathrm{Y}$ (post) & E. coli & Abx, PCD & Recovered & Not given & Cyclo, Aza, Pred \\
\hline $\begin{array}{c}\text { Al-Makadma \& } \\
\text { Al-Akash [19] } 2005\end{array}$ & 12 & M & $\mathrm{N}$ & 5 months & $\mathrm{N}$ & E. coli & Abx & Recovered & Living & Pred, MMF, Tacro \\
\hline $\begin{array}{l}\text { Fujita et al. [20] } \\
\qquad 2005\end{array}$ & 49 & F & $\mathrm{Y}$ & 15 months & Y (pre) & Salmonella & Abx, TN & On HD & Deceased & Cyclo, Pred \\
\hline $\begin{array}{l}\text { Arai et al. [21] } \\
2006\end{array}$ & 61 & M & $\mathrm{Y}$ & 2 years & Y (pre) & E. coli & Abx, TN & Died & Not given & Pred, Cyclo, MMF \\
\hline $\begin{array}{c}\text { Baliga et al. [2] } \\
2007\end{array}$ & 52 & $\mathrm{~F}$ & $\mathrm{~N}$ & 4 days & Y (pre) & E. coli & Abx & Recovered & Living & Cyclo, MMF, Pred \\
\hline $\begin{array}{c}\text { Chuang et al. [22] } \\
2007\end{array}$ & 51 & M & $\mathrm{Y}$ & 15 years & $\mathrm{Y}$ (post) & E. coli & Abx, PCD & Recovered & Deceased & Pred, Tacro, MMF \\
\hline $\begin{array}{l}\text { Boltan et al. [23] } \\
\quad 2008\end{array}$ & 76 & M & $\mathrm{N}$ & 10 years & Y (pre) & Klebsiella & Abx, TN & On HD & Deceased & Cyclo, MMF, Pred \\
\hline $\begin{array}{l}\text { Schmidt et al. [3] } \\
2009\end{array}$ & 55 & M & $\mathrm{N}$ & 10 months & Y (pre) & E. coli & Abx, TN & On HD & Deceased & Did not mention \\
\hline $\begin{array}{l}\text { Al-Geizawi et al. } \\
\text { [6] } 2012\end{array}$ & 58 & M & $\mathrm{Y}$ & 15 months & Y (pre) & Klebsiella & Abx, PCD & Recovered & Deceased & Tacro, MMF \\
\hline $\begin{array}{l}\text { Alexander et al. } \\
\quad \text { [1] } 2012\end{array}$ & 51 & $\mathrm{~F}$ & $\mathrm{~N}$ & 9.5 years & $\mathrm{Y}$ (post) & Klebsiella & Abx, PCD & Recovered & Living & Cyclo, Aza, Pred \\
\hline $\begin{array}{c}\text { Piracha et al. } \\
\text { (current report) } 2014\end{array}$ & 58 & M & $\mathrm{Y}$ & 5 years & Y (pre) & Klebsiella & Abx, TN & On HD & Deceased & MMF, Tacro \\
\hline
\end{tabular}

Key: Abx = antibiotics; TN = transplant nephrectomy; PCD = percutaneous catheter drainage; Pred = prednisone; Aza = azathioprine; Cyclo = cyclosporine; $\mathrm{MMF}$ = mycophenolatemofetil; Tacro = tacrolimus. 
mycophenolate mofetil 7/21 (33\%), and tacrolimus 3/21 (14\%) in various combinations.

Fever, abdominal pain and dysuria were the presenting symptoms in 15/21 patients (71\%), and 2/21 patients (10\%) were asymptomatic with worsening renal function. Importantly, 9/21 patients (43\%) developed multi-organ system dysfunction and septic shock during the hospitalization (Table 1). Escherichia coli and Klebsiella pneumoniae were reported in 13/21 (62\%) and 6/21 (29\%) patients respectively.

With regard the high incidence of EPN in diabetic patients, it has been suggested that the increased tissue and urine glucose levels may provide a favorable microenvironment for gas-forming bacteria [3].

A number of attempts have been made to classify EPN according to severity of clinical presentation, which in turn would guide therapy. In essence all of these classifications are reliant on CT scan results which depict the extent of gas formation [4] [5], and the early response to conservative therapy. Only one such classification exists which addresses EPN in renal allografts [6]. It should also be recognized that this approach was published in 2010, while much of the data summarized in Table 1 pre-dates this classification. Interestingly, 18/21 patients (86\%) had gas present in the renal parenchyma and collecting system whereas 3/21 patients (14\%) had gas only in the renal collecting system.

Once recognized, EPN should be treated with aggressive medical management, primarily parenteral antibiotics, and aggressive optimization of hemodynamic status. Since gram negative bacilli account for the overwhelming number of infections (Table 1), initial empiric antibiotic coverage should take this observation into account. If hemodynamic stability can be attained, percutaneous catheter drainage of the renal pelvis should be undertaken [1] [7]. However, in the setting of multi-organ failure and uncontrolled sepsis, early transplant nephrectomy should be the approach of choice [3] [8]. As summarized in Table 1, 4/21 patients (19\%) recovered with antibiotic therapy only, 7/21 patients (33\%) underwent percutaneous catheter drainage and made a complete recovery, and 10/21 patients (48\%) underwent transplant nephrectomy. Of the latter group, 3/21 of these patients died (mortality rate 14\%).

\section{Conclusion}

In aggregate, EPN carries a high mortality in the diabetic, immunosuppressed renal transplant recipient. We submit that in such individuals who present with graft tenderness, a high index of suspicion is needed to diagnose this entity. For patients with stage 3 EPN [6], timely and judicious transplant nephrectomy may be a lifesaving modality.

\section{References}

[1] Alexander, S., et al. (2012) Extensive Emphysematous Pyelonephritis in a Renal Allograft Treated Conservatively: Case Report and Review of the Literature. Transplant Infectious Disease, 14, E150-E155. http://dx.doi.org/10.1111/tid.12016

[2] Baliga, K.V., et al. (2007) Successful Medical Treatment of Emphysematous Pyelonephritis in a Renal Allograft Recipient. Renal Failure, 29, 755-758. http://dx.doi.org/10.1080/08860220701460434

[3] Schmidt, S., et al. (2009) Emphysematous Pyelonephritis in a Kidney Allograft. American Journal of Kidney Diseases, 53, 895-897. http://dx.doi.org/10.1053/j.ajkd.2008.12.032

[4] Huang, J.J. and C.C. Tseng (2000) Emphysematous Pyelonephritis: Clinicoradiological Classification, Management, Prognosis, and Pathogenesis. Archives of Internal Medicine, 160, 797-805. http://dx.doi.org/10.1001/archinte.160.6.797

[5] Wan, Y.L., et al. (1996) Acute Gas-Producing Bacterial Renal Infection: Correlation between Imaging Findings and Clinical Outcome. Radiology, 198, 433-438.

[6] Al-Geizawi, S.M., et al. (2010) Renal Allograft Failure Due to Emphysematous Pyelonephritis: Successful Non-Operative Management and Proposed New Classification Scheme Based on Literature Review. Transplant Infectious Disease, 12, 543-550. http://dx.doi.org/10.1111/j.1399-3062.2010.00538.x

[7] Vivek, V., Panda, A. and Devasia, A. (2012) Emphysematous Pyelonephritis in a Renal Transplant Recipient-Is It Possible to Salvage the Graft? Annals of Transplantation, 17, 138-141. http://dx.doi.org/10.12659/AOT.883469

[8] Baas, M.C., van Donselaar, K.A., van der Pant and Bemelman, F.J. (2009) Emphysematous Pyelonephritis in a Renal Transplant Patient. The Netherlands Journal of Medicine, 67, 403-404.

[9] Parameswaran, R. and Feest, T. (1977) Gas Nephrogram: An Unusual Complication of Renal Transplantation. British Journal of Radiology, 50, 438-440. http://dx.doi.org/10.1259/0007-1285-50-594-438 
[10] Brenbridge, A.N., et al. (1979) Renal Emphysema of the Tranplanted Kidney: Sonographic Appearance. (AJR) American Journal of Roentgenology, 132, 656-658. http://dx.doi.org/10.2214/ajr.132.4.656

[11] Balsara, V.J., Raval, B. and Maklad, N.F. (1985) Emphysematous Pyelonephritis in a Renal Transplant: Sonographic and Computed Tomographic Features. Journal of Ultrasound in Medicine, 4, 97-99.

[12] Potter, J.L., et al. (1985) Emphysema in the Renal Allograft. Radiology, 155, 51-52.

[13] O’Donnell, D., Rumbak, M. and Anderson, J. (1986) Emphysematous Pyelonephritis in a Transplanted Kidney. Clinical Nephrology, 25, 52-53.

[14] Glen, D., Bayliss, A.P. and Robertson, E.M. (1989) Percutaneous Drainage in Emphysematous Pyelonephritis. Clinical Radiology, 40, 434. http://dx.doi.org/10.1016/S0009-9260(89)80155-2

[15] Kalra, O.P., et al. (1993) Emphysematous Pyelonephritis and Cystitis in a Renal Transplant Recipient-Computed Tomographic Appearance. The International Journal of Artificial Organs, 16, 41-44.

[16] Akalin, E., et al. (1996) Emphysematous Cystitis and Pyelitis in a Diabetic Renal Transplant Recipient. Transplantation, 62, 1024-1026. http://dx.doi.org/10.1097/00007890-199610150-00023

[17] Cheng, Y.T., Wang, H.P. and Hsieh, H.H. (2001) Emphysematous Pyelonephritis in a Renal Allograft: Successful Treatment with Percutaneous Drainage and Nephrostomy. Clinical Transplant, 15, 364-367. http://dx.doi.org/10.1034/j.1399-0012.2001.150511.x

[18] Iqubal, M., et al. (2004) Abdominal Gas Is Not Always Bowel Associated: Lessons from an Allograft Recipient. Nephrology Dialysis Transplantation, 19, 503-504. http://dx.doi.org/10.1093/ndt/gfg465

[19] Al-Makadma, A.S. and Al-Akash, S.I. (2005) An Unusual Case of Pyelonephritis in a Pediatric Renal Transplant Recipient. Pediatric Transplantation, 9, 258-260. http://dx.doi.org/10.1111/j.1399-3046.2004.00276.x

[20] Fujita, S., et al. (2005) Case of Emphysematous Pyelonephritis in a Renal Allograft. Clinical Transplant, 19, 559-562. http://dx.doi.org/10.1111/j.1399-0012.2005.00264.x

[21] Arai, S., et al. (2006) A Case of Emphysematous Pyelonephritis in a Renal Allograft. Transplantation, 81, $296-297$. http://dx.doi.org/10.1097/01.tp.0000191623.83885.ee

[22] Chuang, Y.W., et al. (2007) Severe Emphysematous Pyelonephritis in a Renal Allograft: Successful Treatment with Percutaneous Drainage and Antibiotics. Clinical Nephrology, 68, 42-46. http://dx.doi.org/10.5414/CNP68042

[23] Boltan, L.E., Randall, H. and Barri, Y.M. (2008) Iatrogenic Emphysematous Pyelonephritis in a Renal Transplant Patient. Transplant Infectious Disease, 10, 409-412. http://dx.doi.org/10.1111/j.1399-3062.2008.00319.x 